Creative commons User License: CC BY-NC-ND

Abstracted by: EBSCOhost, Electronic Journals Service (EJS),

Google Scholar, Journal Seek, Scientific Commons,

Food and Agricultural Organization (FAO), CABI and Scopus
Journal of Agricultural Extension

Vol. 22 (1) February, 2018

ISSN(e): 24086851; ISSN(Print); $1119944 X$

http://journal.aesonnigeria.org

http://www.ajol.info/index.php/jae

Email: editorinchief@aesonnigeria.org

\title{
Determinants of Edible Insects Consumption Level in Kogi State, Nigeria
}

\author{
https://dx.doi.org/10.4314/jae.v22i1.14
}

\section{Meludu, Nkiru T.}

Department of Agricultural Extension and Rural Development University of Ibadan, Ibadan, Nigeria,

E-mail: nkiru m@vahoo.com

Phone No: +2348023250457.

\section{Onoja, M. Nelson}

Department of Agricultural Extension and Rural Development, University of Ibadan, Ibadan, Nigeria.

E-mail: nelson.m.onoja@gmail.com

Phone No: +2347031875157 .

\section{Abstract}

The study investigated the determinants of edible insects' consumption level in Kogi State, Nigeria. It specifically carried an inventory of indigenous species of edible insects available to the respondents; ascertained the people's knowledge level of the functional value of insects; their level of consumption and perception of insect farming in the state and identified the constraints to insects' consumption among the population. The study adopted multistage sampling procedure to select a total of 160 rural dwellers from the four ADP zones in the state. Data were collected with the aid of interview schedules and analyzed using descriptive and inferential statistics. Finding shows that cricket, termite, palm weevil, yam beetle, caterpillar, silkworm, and locust respectively were the identified indigenous species of insects being consumed by the people of Kogi State. However, low level of insect consumption was recorded in the state as a result of poor level of knowledge of their functional values and negative perception of insect farming and consumption. The regression analysis results identified respondents' age $(\beta=0.140, P=0.00)$, main occupation $(\beta=3.224, P=0.00)$ and perceived constraints $(\beta=7.255, \quad P=0.00)$ as determinants of the consumption level of insects. The study concludes that insect consumption is a common practice in Kogi State even though on a low scale and therefore recommends among other things, heavy public awareness creation and public education on the health and nutritional benefits of edible insects to mankind and establishment of insects farming training centres by the state Government.

Keywords: Edible insect consumption. 
Creative commons User License: CC BY-NC-ND

Abstracted by: EBSCOhost, Electronic Journals Service (EJS),

Google Scholar, Journal Seek, Scientific Commons,

Food and Agricultural Organization (FAO), CABI and Scopus
Journal of Agricultural Extension

Vol. 22 (1) February, 2018

ISSN(e): 24086851; ISSN(Print); 1119944X

http://journal.aesonnigeria.org

http://www.ajol.info/index.php/jae

Email: editorinchief@aesonnigeria.org

\section{Introduction}

The world's population stands at 7.3 billion people currently, with a projection to be nine billion by 2050 (Food and Agriculture Organisation, FAO, 2013). Africa alone has 16\% (1.2 billion) of the world population of which Nigeria has about 178 million people (United Nations, Department of Economic and Social Affairs, Population Division, UN, DESAPD, 2015). According to FAO (2015), one in every nine people in the world go to bed hungry each night and the vast majority of hungry (chronically malnourished) people, 780 out of 795 million people, live in developing countries. Not fewer than 175.7 million people in Africa live in hunger and the number keep increasing (FAO, 2015). This explains the current global efforts like national food security and food selfsufficiency programmes, aimed at ensuring food security in terms of quantity and quality of food consumed across the globe.

As world leaders, especially the developed countries, seem to be winning the war against food insecurity, Nigeria and Africa at large are fighting hard to manage unavailability/un-affordability of animal protein (meat), that human body required for effective performance. For instance, FAO (2008) as cited in Ebenebe and Okpoko (2015) recommended consumption of $34 \mathrm{~g}$ of animal protein per person per day for normal growth and development. However, animal protein consumption in Nigeria stands averagely at $7-10 \mathrm{~g} /$ person/day as a result of high poverty level and ignorance (Ebenebe and Okpoko, 2015). While meat appears to be unavailable and un-affordable by many Nigerians because of the high poverty level in the country, research evidences have also consistently raised health issues associated with meat consumption (Huis, 2012).

For instance, red meat intake has been significantly associated with risk of cardiovascular disease (CVD) such as coronary heart disease (CHD), stroke and myocardial infarction (MI) (Kontogianni, Panagiotakos, and Pitsavos, 2008; Williamson, Foster, Stanner and Buttriss, 2005 and KelemenKushi and Jacob, 2005). Also, several epidemiological studies, Wei, Giovannucci, Rosner and Fuchs (2004) and Cross, Leitsmann, Gail and Hollenbeck (2007) have identified meat intake to have been significantly associated with risk of colon and rectum cancer. Besides, high consumption of meat has been reported to possess higher intakes of cholesterol.

In an attempt to bridge the gap between animal nutrient deficit and human population growth rate as well as managing the health risks associated with meat consumption, many alternative sources of nutrients, especially micro-livestock, has been recommended to form integral aspect of the nation's traditional farming system and consumption (FAO, 2013). Farming and consumption of edible insects therefore are seen as an important tool in improving the animal nutrient supply in the country (Alamu, Amao, Nwokedi and Oke, 2013). 
Creative commons User License: CC BY-NC-ND

Abstracted by: EBSCOhost, Electronic Journals Service (EJS),

Google Scholar, Journal Seek, Scientific Commons,

Food and Agricultural Organization (FAO), CABI and Scopus
Journal of Agricultural Extension

Vol. 22 (1) February, 2018

ISSN(e): 24086851; ISSN(Print); $1119944 X$

http://journal.aesonnigeria.org

http://www.ajol.info/index.php/jae

Email: editorinchief@aesonnigeria.org

Entomophagy according to Adeoyo, Oyelowe, Adebisi and Akinyemi (2014) is the human consumption of insects as food; it is indigenous to Nigeria and most other African nations. The consumption of edible insects seems to be on a steady decline in recent time besides the fact that real insect farming is seemingly unpopular in most part of the country (Akunne, Ononye and Mogbo, 2013), Kogi State inclusive.

Insects are classified as one of the most successful group of animals on earth constituting about $76 \%$ of all known species of animals; found in nearly all environments; and widely distributed across aquatic ecosystems, farm land and forests (Adegbola, Awagu, Arowora, Ojuekaiye, Anugwom and Kashetu, 2013). Ironically, they have also been rated as the most under-utilized and under exploited creature on earth by mankind in the time past (Huis, 2012). For instance, many persons see insects as an enemy and threat to human existence and as such have grown so merciless and brutal when handling them.

Although, there are more than one million described species of insects, scholars have identified over 1,900 species that have reportedly been used as food (FAO, 2013). The most commonly consumed insects according to FAO (2013) include beetles (Coleoptera) (31\%); caterpillars (Lepidoptera) (18\%), bees, wasps and ants (Hymenoptera) (14\%); grasshoppers, locusts and crickets (Orthoptera) (13\%); cicadas, leafhoppers, plant-hoppers, scale insects and true bugs (Hemiptera) (10\%); termites (Isoptera) (3\%); dragonflies (Odonata) (3\%); flies (Diptera) $(2 \%)$; and others (5\%). Insects are often consumed whole but can also be processed into granular or paste forms (Ekpo, 2011). Generally, the taste and nutritional value of edible insect vary with the species of the insect, the metamorphic stage of the insect, the habitat and its diet (Agbidye, Ofuya and Akindele, 2009).

In spite of the seemingly nutritional, economic, environment, and health benefits of insects however, empirical research evidence documenting insect farming and consumption pattern in Nigeria remains relatively few and that of Kogi State appears almost nonexistence. It is in response to this that this study was conceived to make bare empirical evidence on the determinants of the level of edible insects' consumption and farming in Kogi State, Nigeria. 
Creative commons User License: CC BY-NC-ND

Abstracted by: EBSCOhost, Electronic Journals Service (EJS),

Google Scholar, Journal Seek, Scientific Commons,

Food and Agricultural Organization (FAO), CABI and Scopus

\section{Objective of the study}

Journal of Agricultural Extension

Vol. 22 (1) February, 2018

ISSN(e): 24086851; ISSN(Print); 1119944X

http://journal.aesonnigeria.org

http://www.ajol.info/index.php/jae

Email: editorinchief@aesonnigeria.org

The specific objectives of this study were to:

1. identify the indigenous species of edible insects available;

2. ascertain the respondents' level of knowledge of the functional value of edible insects;

3. determine respondents' level of edible insects' consumption;

4. ascertain the determinants of edible insects' consumption;

5. determine the respondents' perception of insect farming; and

6 . identify constraints to edible insects' consumption among respondents.

\section{Hypotheses of the study}

$\mathrm{H}_{0} 1$ : There is no significant relationship between socioeconomic characteristics of respondents and level of edible insect consumption in the study area.

$\mathrm{H}_{0}$ 2. There is no significant relationship between respondents' knowledge on the nutritional value of edible insects and their level of consumption.

Ho3. There is no significant relationship between respondents' perception of edible insects and their level of consumption.

\section{Methodology}

The study was conducted in Kogi State, with headquarters in Lokoja (Awoyemi, Obayelu and Opaluwa, 2011). Kogi State is located in the north central part of Nigeria, on latitude $7.4 \mathrm{~N}$ and longitude $6.45 \mathrm{E}$ and with a land area of approximately $28,313.53$ square kilometres (Alabi and Ocholi, 2010). The State has an average temperature of $33.2^{\circ} \mathrm{C}$ and average minimum degree of $22.8^{\circ} \mathrm{C}$.

Kogi state has two distinct weather;dry season, which lasts from November to February and rainy season that last from March to October (Awoyemiet al., 2011). Demographically, Kogi State has a total population of 3,314,043 people (National Population Commission, 2006); The state comprises three (3) senatorial districts and twenty-one (21) local government areas. The study focused on rural dwellers in Kogi State.

Multi-stage sampling procedure was employed in selecting respondents for the study using purposive and simple random sampling techniques. In the first instance, one ADP block (Local Government Area) was purposively selected from each of the four (4) ADP zones in Kogi state giving a total of four (4) ADP Blocks for the study. This is to be sure that the four selected ADP blocks cut across the four major ethnic groups in Kogi state (Igalas, Yorubas, Ebira and Bassa). Secondly, two ADP circles each were randomly selected from the four (4) selected ADP blocks, to arrive at eight (8) ADP circles. Thirdly, two ADP cells (Villages) each were randomly selected from the eight (8) selected ADP circles, to arrived at sixteen (16) ADP cells for the study. Finally, ten (10) 
Creative commons User License: CC BY-NC-ND

Abstracted by: EBSCOhost, Electronic Journals Service (EJS), Google Scholar, Journal Seek, Scientific Commons,

Food and Agricultural Organization (FAO), CABI and Scopus
Journal of Agricultural Extension

Vol. 22 (1) February, 2018

ISSN(e): 24086851; ISSN(Print); $1119944 X$

http://journal.aesonnigeria.org

http://www.ajol.info/index.php/jae

Email: editorinchief@aesonnigeria.org

respondents each were randomly selected from each of the sixteen (16) selected ADP cells, giving a total of one hundred and sixty (160) respondents for the study.

An interview schedule was used for data collection. Data collected were analyzed using: descriptive and inferential statistics. The formulated hypotheses were tested using chisquare, pearson product moment correlation (PPMC) and regression analysis.

\section{Results and Discussion}

\section{Selected Socioeconomic Characteristics of Respondents}

Table 1, reveals that the majority of the respondents $(74.4 \%)$ had at least primary educational experience, both sexes (male $=57.1 \%$ and female $=42.9 \%$ ) were fairly represented in the study, a majority of them $(53.8 \%)$ were married with a mean age of 40.2 years and earned on the average $\$ 33,338$ per month. 
Creative commons User License: CC BY-NC-ND

Abstracted by: EBSCOhost, Electronic Journals Service (EJS),

Google Scholar, Journal Seek, Scientific Commons,

Food and Agricultural Organization (FAO), CABI and Scopus
Journal of Agricultural Extension

Vol. 22 (1) February, 2018

ISSN(e): 24086851; ISSN(Print); 1119944X

http://journal.aesonnigeria.org

http://www.ajol.info/index.php/jae

Email: editorinchief@aesonnigeria.org

Table 1: Distribution of respondents' socioeconomic characteristics

\begin{tabular}{|c|c|c|}
\hline Variable & Percentage (\%) & Mean \\
\hline \multicolumn{3}{|l|}{ Age (Years) } \\
\hline$\leq 30$ & 11.5 & \\
\hline $31-40$ & 28.9 & 40.2 \\
\hline $41-50$ & 34.6 & \\
\hline $51-60$ & 10.9 & \\
\hline $61-70$ & 8.3 & \\
\hline$\geq 70$ & 5.8 & \\
\hline Total & 100 & \\
\hline \multicolumn{3}{|l|}{ Sex } \\
\hline Male & 57.1 & \\
\hline Female & 42.9 & \\
\hline \multirow{2}{*}{\multicolumn{3}{|c|}{ Religion }} \\
\hline & & \\
\hline Christianity & 50.0 & \\
\hline Islam & 44.2 & \\
\hline Traditional & 5.8 & \\
\hline Total & 100 & \\
\hline \multicolumn{3}{|l|}{ Marital Status } \\
\hline Single & 36.5 & \\
\hline Married & 53.8 & \\
\hline Divorced & 5.8 & \\
\hline Windowed & 2.6 & \\
\hline Separated & 1.3 & \\
\hline \multicolumn{3}{|l|}{ Level of education } \\
\hline No formal education & 25.6 & \\
\hline Primary education & 16.7 & \\
\hline Secondary education & 42.9 & \\
\hline \multirow{2}{*}{\multicolumn{3}{|c|}{ Main occupation }} \\
\hline & & \\
\hline Civil service & 23.1 & \\
\hline Farming & 32.7 & \\
\hline Trading & 28.2 & \\
\hline Artisan & 7.1 & \\
\hline Student & 9.0 & \\
\hline \multicolumn{3}{|l|}{ Monthly income } \\
\hline$\leq 20,000$ & 26.9 & \\
\hline $21,000-40,000$ & 40.4 & \\
\hline $41,000-60,000$ & 27.6 & \\
\hline $61,000-80,000$ & 3.9 & \\
\hline$\geq 81,000$ & 1.3 & N33'338 \\
\hline
\end{tabular}

Source: Field survey, 2016.

Indigenous Species of Edible Insects in Kogi State

Table 2, shows that cricket $(98.7 \%)$, termite $(90.4 \%)$, palm weevil $(69.9 \%)$, yam beetle (35.9\%), caterpillar (34.6\%), silkworm (11.6\%) and lastly locust $(3.9 \%)$ as the 
Creative commons User License: CC BY-NC-ND

Abstracted by: EBSCOhost, Electronic Journals Service (EJS),

Google Scholar, Journal Seek, Scientific Commons,

Food and Agricultural Organization (FAO), CABI and Scopus
Journal of Agricultural Extension

Vol. 22 (1) February, 2018

ISSN(e): 24086851; ISSN(Print); 1119944X

http://journal.aesonnigeria.org

http://www.ajol.info/index.php/jae

Email: editorinchief@aesonnigeria.org

acceptable indigenous species of insects being consumed by the people of Kogi State, suggesting that insect consumption is widespread in the area as a way of complimenting the nutritional needs of the people of the State. Meanwhile, none of the respondents admitted eating grasshopper and bee.

The study also observed that insect consumption cuts across all the four major ethnic groups surveyed in the state (Igalas, Yorubas, Ebira and Bassa communities), as well as religions with slight difference in gender and age. Therefore, the reported number of acceptable edible insects by respondents in Table 2, indicates that insects are cherished by the rural dwellers in Kogi State, Nigeria as it is the case in many other parts of Nigeria and the World at large (Agbidyeet. al., 2009; Ajayi and Adedire, 2007 and Mbata and Chidumayo, 2003). In a nutshell, the findings of this study show that Kogi State is not left out in the consumption of cricket and termites as shown in earlier studies conducted elsewhere across the country like Agbidyeet. al. (2009); Ajayi and Adedire (2007); Adeduntan and Bada (2004); Mbata and Chidumayo (2003).

Table 2: Distribution of respondents by indigenous species of edible insects available in their area of residence

\begin{tabular}{lll} 
Edible insect & Yes & Rank \\
\hline Cricket & 98.7 & $1^{\text {st }}$ \\
Termite & 90.4 & $2^{\text {nd }}$ \\
Palm weevil & 69.9 & $3^{\text {rd }}$ \\
Yam beetle & 35.9 & $4^{\text {th }}$ \\
Caterpillar & 34.6 & $5^{\text {th }}$ \\
Silkworm & 11.5 & $6^{\text {th }}$ \\
Locust & 3.9 & $7^{\text {th }}$
\end{tabular}

NB: Figures in parentheses are percentages. Source: Field survey, 2016.

\section{Respondents' Knowledge of Functional Values of Edible}

Table 3 shows that respondents' knowledge of functional values of edible insects was highest for the statement edible insect is a healthy source of food for children $(\bar{x}=0.91)$, followed by edible insects do add taste to food when fried $(\bar{x}=0.88)$, edible insects can be roasted and consumed as food $(\bar{x}=0.87)$ "edible insects aids growth and development in children $(\bar{x}=0.81)$ and "edible insects contain iron which promote healthy blood formation" ( $\bar{x}=0.77)$.

Also, the categorisation of respondents' level of knowledge of functional values of edible insects further confirmed that more than half of the respondents, $58.3 \%$, had knowledge mean score of $\geq 10.64$ (indicating fairly high level of knowledge). However, by implication, the acceptance of these insects as vital component of human feed in Kogi 
Creative commons User License: CC BY-NC-ND

Abstracted by: EBSCOhost, Electronic Journals Service (EJS),

Google Scholar, Journal Seek, Scientific Commons,

Food and Agricultural Organization (FAO), CABI and Scopus
Journal of Agricultural Extension

Vol. 22 (1) February, 2018

ISSN(e): 24086851; ISSN(Print); $1119944 X$

http://journal.aesonnigeria.org

http://www.ajol.info/index.php/jae

Email: editorinchief@aesonnigeria.org

State may be impeded looking at the fact that close to half of the respondents $(41.7 \%)$ had little or no knowledge of the functional values of edible insects. This calls for heavy public education and awareness on the health and nutritional benefits of edible insects to the people of Kogi State.

Table 3: Distribution of respondents based on their knowledge of functional values of edible insects' consumption

\begin{tabular}{lll}
\hline Statement & Yes & Mean $(\bar{x})$ \\
\hline Edible insects contain minerals (e.g Calcium) & 74.4 & 0.74 \\
Edible insects do not contain fats & 45.5 & 0.55 \\
Edible insect is a healthy source of food for children & 91.0 & 0.91 \\
Edible insect and its products can be use in place of meat in food & 70.5 & 0.71 \\
Edible insects do not contain protein & 36.5 & 0.64 \\
Edible insects do add taste to food when fried & 87.8 & 0.88 \\
Edible insect is lower in cholesterol content & 53.9 & 0.54 \\
Edible insects contain iron which promote healthy blood formation & 76.9 & 0.77 \\
Insects lack phosphorus which aids bones and teeth formation & 41.0 & 0.59 \\
Edible insects reduce the palatability of food & 38.5 & 0.62 \\
Edible insects are medicinal in nature & 73.1 & 0.73 \\
Edible insects aids growth \& development in children & 81.4 & 0.81 \\
Edible insects can be eaten raw & 47.4 & 0.47 \\
Edible insect supply energy to the body & 68.6 & 0.31 \\
Edible insects are not healthy source of food for adults & 50.6 & 0.50 \\
Edible insects can be roasted and consumed as food & 87.2 & 0.87 \\
\hline
\end{tabular}

Source: Field survey, 2016.

\section{Level of Consumption of Edible Insects}

Table 4 shows that respondents' level of edible insects consumption was highest for cricket $(\bar{x}=4.39)$, followed by termite $(\bar{x}=3.67)$ and palm weevil $(\bar{x}=2.37)$. However, none of the respondents agreed to have consumed grasshopper and bee in all the villages visited. Also, the categorisation of respondents' level of edible insects' consumption shows that the greater percentage of the respondents $(89.7 \%)$ had consumption mean score of $\leq 12.41$, indicating a very low level of consumption of edible insects in the area. 
Creative commons User License: CC BY-NC-ND

Abstracted by: EBSCOhost, Electronic Journals Service (EJS),

Google Scholar, Journal Seek, Scientific Commons,

Food and Agricultural Organization (FAO), CABI and Scopus
Journal of Agricultural Extension

Vol. 22 (1) February, 2018

ISSN(e): 24086851; ISSN(Print); $1119944 X$

http://journal.aesonnigeria.org

http://www.ajol.info/index.php/jae

Email: editorinchief@aesonnigeria.org

Table 4: Level of edible insects' consumption

\begin{tabular}{lll}
\hline Edible insect & Mean $(\bar{x})$ & Rank \\
\hline Cricket & 4.39 & $1^{\text {st }}$ \\
Termite & 3.67 & $2^{\text {nd }}$ \\
Palm weevil & 2.37 & $3^{\text {rd }}$ \\
Yam beetle & 0.96 & $4^{\text {th }}$ \\
Caterpillar & 0.85 & $5^{\text {th }}$ \\
Silkworm & 0.22 & $6^{\text {th }}$ \\
Locust & 0.08 & $7^{\text {th }}$
\end{tabular}

NB: Mean score $\geq 1.4$ indicates high level of consumption. Source: Field survey, 2016

\section{Determinants of Edible Insect Consumption}

Table 5, shows that respondents' age $(\beta=0.140, p=0.00)$, main occupation $(\beta=3.224$, $p=0.00)$ and perceived constraints $(\beta=7.255, p=0.00)$ are the underlining factors contributing significantly to the consumption of edible insects. As people get older they become more cautious of the kind of food items they consume and as such the preference and quest for a healthier, cost effective, nutritional, medicinal friendly food alternative like edible insects and its products tend to increase.

Table 5: Determinants of edible insects' consumption level

\begin{tabular}{lll}
\hline Variable & $\boldsymbol{\beta}$-value & t-value \\
\hline Constant $\left(\beta_{0}\right)$ & 2.949 & -1.288 \\
Age & 0.140 & $2.859^{* \star}$ \\
Sex & 0.015 & 0.409 \\
Religion & 0.003 & 0.081 \\
Educational level & -0.034 & -0.804 \\
Marital status & 0.035 & 0.816 \\
Household size & 0.041 & 1.197 \\
Main occupation & -0.119 & $3.224^{\star *}$ \\
Average monthly income & -0.007 & 0.179 \\
Knowledge & 0.055 & 1.553 \\
Perception & 0.035 & 0.986 \\
Constraints & 0.900 & $7.255^{\star \star}$ \\
\hline
\end{tabular}

${ }^{* *} p \leq 0.05, R^{2}=0.852, d f=10$ and $n=156$. Source: Field survey, 2016 .

\section{Perception of Edible Insects Farming}

Table 6 shows the respondents' perception of edible insects farming and consumption in the area. The respondents strongly believed that edible insects farming and consumption practices can be lucrative if embraced by all $(\bar{x}=3.6)$ and as well affirmed 
Creative commons User License: CC BY-NC-ND

Abstracted by: EBSCOhost, Electronic Journals Service (EJS),

Google Scholar, Journal Seek, Scientific Commons,

Food and Agricultural Organization (FAO), CABI and Scopus
Journal of Agricultural Extension

Vol. 22 (1) February, 2018

ISSN(e): 24086851; ISSN(Print); $1119944 X$

http://journal.aesonnigeria.org

http://www.ajol.info/index.php/jae

Email: editorinchief@aesonnigeria.org

that insects farming and consumption could translate to improved community health if given adequate attention $(\bar{x}=3.1)$.

However, the respondents further observed that the most outstanding reasons why a lot of persons may not practice entomophagy is due to the facts that insects are seen as poor people's food in the society; for instance, the majority $(\bar{x}=3.0)$ of the respondents believe that insects are meant for those who cannot afford meat.

Key informants noted that the practice of entomophagy has been on the decline in the area due to civilization and that it is no longer a common practice among the elites and those currently practicing it were being stigmatized. This finding corroborates the reports of Ebenebe et al. (2015), from the South-Eastern Nigeria; that insects eating were greatly associated with poverty as the rich/elites dropped the habits for the poor and the so called illiterates in the rural communities.

Also, on the categorisation of respondents' perception of edible insects' consumption further confirmed that the greater percentage of the respondents $(55.8 \%)$ had perception mean score of $\leq 44.8$, indicating a fairly high negative perception towards edible insects in the area. This goes to show that to fully harness the numerous benefits of insect consumption in the state, a lot of attitudinal change campaigns needs to be organised to strategically and positively position the edible insects and it products on the minds of the end users. 
Creative commons User License: CC BY-NC-ND

Abstracted by: EBSCOhost, Electronic Journals Service (EJS),

Google Scholar, Journal Seek, Scientific Commons,

Food and Agricultural Organization (FAO), CABI and Scopus
Journal of Agricultural Extension

Vol. 22 (1) February, 2018

ISSN(e): 24086851; ISSN(Print); $1119944 X$

http://journal.aesonnigeria.org

http://www.ajol.info/index.php/jae

Email: editorinchief@aesonnigeria.org

Table 6: Mean distribution of respondents by perception of edible insects farming and consumption

\begin{tabular}{lll}
\hline Statement & Mean $(\bar{x})$ & Rank \\
\hline Edible insect farming can be lucrative if embraced by all & 3.6 & $1^{\text {st }}$ \\
Insect consumption could translate to improved community health & 3.1 & $2^{\text {nd }}$ \\
Edible Insects are meant for those who cannot afford meat & 3.0 & $3^{\text {rd }}$ \\
Less satisfaction is derived from the consumption of insects & 2.9 & $4^{\text {th }}$ \\
Insect offers healthier protein source & 2.9 & $4^{\text {th }}$ \\
Always scared of their physical body structure & 2.8 & $6^{\text {th }}$ \\
Edible insects are food for poor people in the society & 2.8 & $6^{\text {th }}$ \\
People that eat edible insects regularly always live long & 2.7 & $8^{\text {th }}$ \\
Don't normally eat insects because they appear very small in size & 2.7 & $8^{\text {th }}$ \\
Substituting all other meat sources for edible insect is worthwhile & 2.6 & $10^{\text {th }}$ \\
Edible insects are more expensive than meats & 2.5 & $11^{\text {th }}$ \\
Edible insects' consumption has higher poisoning tendency & 2.4 & $12^{\text {th }}$ \\
Insects do carry diseases and as such not good for consumption & 2.4 & $12^{\text {th }}$ \\
Food cooked with edible insects taste better & 2.2 & $14^{\text {th }}$ \\
People should be encouraged to farm and consume edible insects & 2.1 & $15^{\text {th }}$ \\
Edible insects should not be served as food in public gatherings & 2.1 & $15^{\text {th }}$ \\
Profit from edible insect farming is less when compare to others & 2.0 & $17^{\text {th }}$
\end{tabular}

NB: Mean score $(\bar{x}) \geq 3.0$ suggest major perception. Source: Field survey, 2016

\section{Constraints to Edible Insects Consumption}

Table 7 reveals that individual cultural diversities $(\bar{x}=2.44)$; poor supply of edible insects $(\bar{x}=2.40)$; lack of hygienic source of edible insects $(\bar{x}=2.35)$; unattractive size of edible insects $(\bar{x}=2.16)$; seasonality of the edible insects $(\bar{x}=2.05)$; and lack of knowledge on nutritional value of edible insects by respondents $(\bar{x}=2.05)$ were the major constraints affecting the individual choices and as well as consumption habits.

These findings uphold the submission of Alamu et. al. (2013) which reported the influence of season in availability of common edible insects consumed in Nigeria. According to them, Rhinocerous bettle (Orytces monocerous) is more common between June-July, Termites (Macrotermes bellicosus) between May to July and Crickets, (Gymnogrylluslucens) July to September. 
Creative commons User License: CC BY-NC-ND

Abstracted by: EBSCOhost, Electronic Journals Service (EJS),

Google Scholar, Journal Seek, Scientific Commons,

Food and Agricultural Organization (FAO), CABI and Scopus
Journal of Agricultural Extension

Vol. 22 (1) February, 2018

ISSN(e): 24086851; ISSN(Print); $1119944 X$

http://journal.aesonnigeria.org

http://www.ajol.info/index.php/jae

Email: editorinchief@aesonnigeria.org

Table 7: Mean distribution of respondents by constraints to edible insects consumption

\begin{tabular}{lll}
\hline Constraint & Mean $(\bar{x})$ & Rank \\
\hline Cultural belief & 2.43 & $1^{\text {st }}$ \\
Poor supply of edible insects & 2.40 & $2^{\text {nd }}$ \\
Source of edible insects & 2.35 & $3^{\text {rd }}$ \\
Unattractive size of edible insects & 2.16 & $4^{\text {th }}$ \\
Seasonality nature of edible insects & 2.05 & $5^{\text {th }}$ \\
Lack of knowledge on nutritional value & 2.05 & $5^{\text {th }}$ \\
Insects has irritating physical structure & 1.85 & $7^{\text {th }}$ \\
Superstitious belief & 1.71 & $8^{\text {th }}$ \\
Unpleasant odour of edible insects & 1.62 & $9^{\text {th }}$ \\
Unattractive colour of edible insects & 1.54 & $10^{\text {th }}$ \\
Edible insects contain poison & 1.28 & $11^{\text {th }}$
\end{tabular}

Mean score $\geq 2.0$ suggest major constraints. Source: Field survey, 2016

Relationship between the socioeconomic characteristics of respondents and level of edible insects' consumption

Table 8 reveals that there is a positive and significant relationship between sex $\left(x^{2}=\right.$ 49.410, $p=0.020)$, level of education $\left(x^{2}=126.463, p=0.000\right)$ marital status $\left(x^{2}=\right.$ 142.774, $p=0.001)$, main occupation $\left(x^{2}=154.409, p=0.000\right)$ and level of edible insects' consumption. Thus, the null hypothesis is therefore rejected. It can be deduced that as an individual get more exposed to formal education, they get civilized and the better they are bound to respond to innovation. The finding corroborates the summation of Fadairo, Olutegbe and Tijani (2015) that says the basic objective of any form of education is to impact knowledge which would influence a change in attitude, skills, or knowledge. Also, when people get married, they tend to assume more responsibility and as such their drive to explore healthier, medicinal and economically friendly nutritional practices like entomophagy increases.

Table 8: Dependence of edible insect consumption on socioeconomic characteristics

\begin{tabular}{lll}
\hline Variable & $\mathbf{X}^{2}$-value & Df \\
\hline Sex & $49.410^{* *}$ & 1 \\
Religion & 56.990 & 2 \\
Level of education & $126.463^{* *}$ & 3 \\
Marital status & $142.774^{* *}$ & 4 \\
Main occupation & $154.409^{* *}$ & 3 \\
\hline
\end{tabular}

${ }^{* *} p \leq 0.05$ = significant. Source: Field survey, 2016 
Creative commons User License: CC BY-NC-ND

Abstracted by: EBSCOhost, Electronic Journals Service (EJS),

Google Scholar, Journal Seek, Scientific Commons,

Food and Agricultural Organization (FAO), CABI and Scopus
Journal of Agricultural Extension

Vol. 22 (1) February, 2018

ISSN(e): 24086851; ISSN(Print); $1119944 X$

http://journal.aesonnigeria.org

http://www.ajol.info/index.php/jae

Email: editorinchief@aesonnigeria.org

\section{Conclusion and Recommendations}

The study concludes that insects' consumption is a common practice in Kogi State even though on a low scale. The study therefore recommends among other things: Heavy public awareness creation and public education on the health and nutritional benefits of edible insects to mankind.

Establishment of insects farming training centres by the state government to encourage farmers to go into large scale production of insects; so as to step up the availability of insects and meet the consumers' demand. This will also reduce relying on the unhygienic natural habitants that had discouraged many from consuming insects in the state. There is also need to develop other ways of preparing edible insects to make them more attractive especially to the group of persons who see insects as having unattractive sizes.

\section{Reference}

Adeduntan, S. A. and F.A. Bada (2004). Socioeconomic importance of local silkworm (Anaphe venata) to the rural dwellers in Ondo state, Nigeria. Abstracts of papers presented at the 35th Annual Conference of the Entomological Society of Nigeria held at the Federal University of Akure, $3-7$, October, 2004, Pp:7-10.

Adegbola, A. J., Awagu F. E., Arowora K., Ojuekaiye O., Anugwom U., and Kashetu Q. R. (2013). Entomophagy: A Panacea for Protein-Deficient- Malnutrition and Food Insecurity in Nigeria. Canadian Center of Science and Education. Journal of Agricultural Science. Available online at http://dx.doi.org/10.5539/jas.v5n6p25. Vol. 5 (6). 25-31.

Adeoyo, O. T., Oyelowe O. J., Adebisi-Fagbohungbe T. A. and Akinyemi O. D. (2014). Eco Diversity of Edible Insects of Nigeria and Its Impact on Food Security. Journal of Biology and Life Science. Available online at www.macrothink.org/ibls. Vol. 5 (2). Pp: 176-188.

Agbidye, F. S. Ofuya, T. I. and Akindele, S. O. (2009). Marketability and Nutritional Qualities of Some Edible Forest Insects in Benue State, Nigeria. Pakistan Journal of Nutrition 8 (7). Pp: 917-922.

Ajayi, O.E. and Adedire, C. O. (2007). Nutrient Characteristics of the Subterranean Termite, Macrotermes subhyalinus (Rambur) (Isoptera: Termitidae). Nigeria Journal of Entomology. Vol. 24: Pp: 42-47.

Akunne, C. E., Ononye, B. U. and Mogbo, T. C. (2013). Insects: Friends or Enemies? Global Journal of Biology, Agriculture and Health Science. Available athttp://www.researchgate.net/publication/258342221. Vol.2(3):134-140. 
Creative commons User License: CC BY-NC-ND

Abstracted by: EBSCOhost, Electronic Journals Service (EJS),

Google Scholar, Journal Seek, Scientific Commons,

Food and Agricultural Organization (FAO), CABI and Scopus
Journal of Agricultural Extension

Vol. 22 (1) February, 2018

ISSN(e): 24086851; ISSN(Print); $1119944 X$

http://journal.aesonnigeria.org

http://www.ajol.info/index.php/jae

Email: editorinchief@aesonnigeria.org

Alamu, O. T., Amao, A. O., Nwokedi, C. I., Oke, O. A. and Lawal, I. O. (2013). Diversity and Nutritional Status of Edible Insects in Nigeria: A Review. Journal of Biodiversity and Conservation. Vol. 5, No. 4. Pp: 215- 221.

Alabi, M. O. and Ocholi, I. (2010). State of Infrastructure and Funding in Kogi State, Nigeria. Current Research Journal of Social Sciences 2(3): 209-213.

Awoyemi, T. T., Obayelu, O. A. and Opaluwa, H. I. (2011). Effect of Distance on Utilization of Health Care Services in Rural Kogi State, Nigeria. Journal of Humuman Ecology. 35(1): 1-9.

Cross, A. J., Leitzmann, M. F., Gail, M. H., Hollenbeck, A. R., Schatzkin, A., and Sinha, R.(2007). A prospective study of red and processed meat intake in relation to cancer risk. PLos Medicine, 4(12), P. 1973.

Ebenebe, C. I. and Okpoko, V. O. (2015). Edible insect consumption in the South Eastern Nigeria. International Journal of Scientific and Engineering Research. Vol. 6, Issue 6. Available at: www.ijser.org.

Ekpo, K. E. (2011). Effect of processing on the protein quality of four popular insectsconsumed in Southern Nigeria. Archives of Applied Science Research.Available online at www.scholarsresearchlibrary.com. Vol. 3 (6):307-326.

Fadairo, O. S., Olutegbe, N. S., and Tijani, A. M. (2015). Attitude of crop farmers towards ewallet platform of the Growth Enhancement Support Scheme for input delivery in OkeOgun area of Oyo state. Journal of Agricultural Informatics. 6(2), 62-77. doi: 10.17700/jai.2015.6.2.184

Food and Agriculture Organization (FAO) (2013). Edible insects: future prospects for food and feed security food and agriculture organization of the united nations. Rome. Pp. 161370.

Food and Agriculture Organization (FAO) (2015), the state of insecurity in the World, Strengthening the enable environment for Food security and Nutrition. Rome. Pp 1-62. Available online at http://www.fao.org/3/a4ef2d16-70a7-460a-a9ac2a65a533269a/i4646e.pdf

Food and Agriculture Organization (FAO) (2008). Locust watch: locust and other migratory pests group. Available online at: http://www.fao.org/ag/locusts/en/info/info/index.html.

United Nations, Department of Economic and Social Affairs, Population Division (UN, DESAPD) (2015). World Population Prospects: The 2015 Revision. New York: United Nations.

Huis, V. A. (2012). Feed in Assuring Food Security. Annual Review of Entomology. DOI:10.1146/annurev-ento-120811-153704. Available at: www.annualreviews.org

Kelemen, L. E., Kushi, L. H., Jacobs, D. R. and Cerhan, J. R. (2005). Associations of dietary protein with disease and mortality in a prospective study of postmenopausal women. American Journal of Epidemiology. 161, 239-249. 
Creative commons User License: CC BY-NC-ND

Abstracted by: EBSCOhost, Electronic Journals Service (EJS),

Google Scholar, Journal Seek, Scientific Commons,

Food and Agricultural Organization (FAO), CABI and Scopus
Journal of Agricultural Extension

Vol. 22 (1) February, 2018

ISSN(e): 24086851; ISSN(Print); 1119944X

http://journal.aesonnigeria.org

http://www.ajol.info/index.php/jae

Email: editorinchief@aesonnigeria.org

Kontogianni, M. D., Panagiotakos, D. B., Pitsavos, C., Chrysohoou, C., and Stefanadis, C. (2008). Relationship between meat intake and the development of acute coronary syndromes: The CARDIO2000 case-control study. European Journal of Clinical Nutrition. Vol. 62, 171-177.

Mbata, K. J. and Chidumayo E. N. (2003). Traditional Value of Caterpillars (Insecta: Lepidoptera) among the Bisa people of Zambia. Insect Science Applied Journal. Vol. 23: 341-354.

Rogers, E. M. (1995). Diffusion of innovations. Retrieved on 09/02/2016 from https://web. stanford.edu/class/symbsys205/Diffusion\%20of\%20Innovations.htm

Williamson, C. S., Foster, R. K., Stanner, S. A., and Buttriss, J. L. (2005). Red meat in the diet. British Nutrition Foundation. Nutrition Bulletin. Vol.30. Pp: 323-355.

Wei, E. K., Giovannucci, E., Wu, K., Rosner, B., Fuchs, C. S. and Willett, W. C. (2004).Comparison of risk factors for colon and rectal cancer. International Journal of Cancer. Vol. 108, 433-442. 